\title{
Histopathology of Goussia clupearum (Protozoa: Apicomplexa: Coccidia) in some marine fish from Scottish waters
}

\author{
G. Costa $^{1}$, K. MacKenzie ${ }^{2}$ \\ ${ }^{1}$ Universidade de Madeira, Area de Biologia, Largo do Colegio, P-9000 Funchal, Madeira, Portugal \\ ${ }^{2}$ SOAFD Marine Laboratory, PO Box 101, Victoria Road, Aberdeen AB9 8DB, United Kingdom
}

\begin{abstract}
The histopathology of liver coccidiosis due to Goussia clupearum was studied in herring Clupea harengus, mackerel Scomber scombrus, Norway pout Trisopterus esmarkii and poorcod Trisopterus minutus from Scottish waters. No macroscopic lesions were observed. Histopathological changes were most pronounced in herring and mackerel and 'yellow bodies' were seen only in these 2 host species. Host inflammatory cells - mainly lymphocytes, phagocytes (macrophages) and eosinophils responded against sporonts and oocysts, but not against earlier developmental stages of the parasite. Accumulations of lipofuscin were seen around some oocysts and macrogamonts and in some uninfected hepatocytes. The host response was less pronounced in Norway pout, but some destruction of sporonts and oocysts was observed. Degenerate hepatocytes containing macrogametes or sporonts were seen in herring. mackerel and Norway pout. In poorcod, levels of infection were low and there was no host response. In the 4 host species studied, liver coccidiosis appears to be well controlled by the host inflammatory system and $G$. clupearum is therefore not a serious pathogen.
\end{abstract}

KEY WORDS: Histopathology - Goussia clupearum - Liver - Marine fish

\section{INTRODUCTION}

Goussia clupearum (Thélohan, 1894) has been found parasitizing the livers of at least 9 species of clupeoid and 2 species of scombroid marine fish (Dyková \& Lom 1983, Love \& Moser 1983). MacKenzie (1981) reported Goussia sp. (as Eimeria sp.) from the liver of the marine gadoid blue whiting Micromesistius poutassou. In the present study the coccidians found in the livers of the gadoids Norway pout Trisopterus esmarkii and poorcod Trisopterus minutus were identical morphologically to $G$. clupearum and to the species from blue whiting. On morphological criteria we have therefore identified the coccidian from these 3 species of gadoid fish as $G$. clupearum. Overstreet et al. (1984) listed 2 other gadoid species - Pollachius pollachius and Merluccius merluccius - as hosts of $G$. clupearum, but we have been unable to trace the original reports. Jones (1990) pointed out the close morphological similarity between $G$. clupearum and Goussia auxidis (Dogiel, 1948), reported from several species of scom- broid fish, and suggested that they may be conspecific There is increasing evidence that piscine coccidians do not have the narrow host specificity characteristic of mammalian and avian coccidians (Dyková \& Lom 1981, 1983, Oliviera et al. 1993)

This study gives further information on the histopathology of Goussia clupearum in herring and mackerel and describes its histopathology in 2 new gadoid hosts - Norway pout and poorcod.

\section{MATERIALS AND METHODS}

Samples of liver tissue from herring, mackerel, Norway pout and poorcod were callected at sea, fixed for light microscopy in either Bouin's fluid or buffered formal saline and embedded in paraffin. Sections were stained with haematoxylin \& eosin, Schmorl's reaction for lipofuscin, Perl's Prussian blue for ferric salts, and PAS, following procedures described in Culling (1974) 


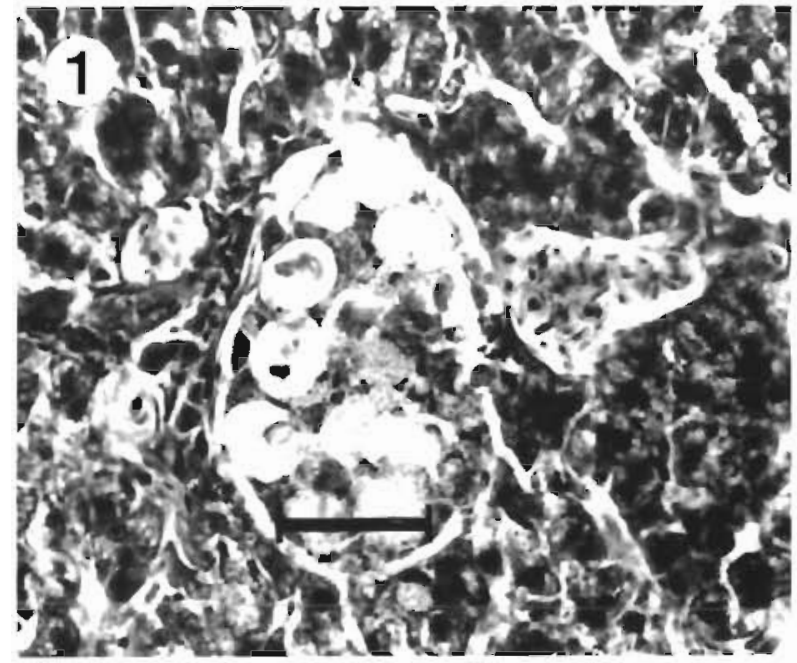

Fig. 1 Goussia clupearum. An aggregation of sporulated and unsporulated oocysts in the liver of a mackerel. Scale bar = $30 \mathrm{~mm}$

For electron microscopy, samples of infected and uninfected livers were fixed in $3 \%$ glutaraldehyde in $0.13 \mathrm{M}$ Millonig's phosphate buffer ( $\mathrm{pH} 7.3$ ), $2 \%$ paraformaldehyde $+2.5 \%$ glutaraldehyde in $0.1 \mathrm{M}$ Sorensen's phosphate buffer ( $\mathrm{pH} 7.2$ ), or in $3 \%$ glutaraldehyde in $0.1 \mathrm{M}$ Sorensen's phosphate buffer ( $\mathrm{pH} 7.2$ ), postfixed in $1 \%$ osmium tetroxide, dehydrated in either acetone or ethanol and propylene oxide and embedded in Agar 100 (glycolmethacrylate). Ultrathin sections were mounted in formvar-coated copper grids and contrasted with $25 \%$ uranyl acetate in $100 \%$ methanol and Reynolds lead citrate

\section{RESULTS}

\section{Light microscopy}

Mackerel. In heavily infected mackerel, aggregations of sporulated and unsporulated oocysts adjacent to hepatic vessels were often enveloped in a yellowishbrown matrix composed of liver cells and oocysts (Fig. 1), sometimes enveloped in a thin fibrotic capsule. These structures stained negatively for ferric salts, lightly for lipofuscin and were PAS positive. They were considered to be the 'yellow bodies' described by several authors from fish infected with coccidians. Each body consisted of a granular part formed by amylopectin granules from the parasite and another formed from necrotic or aggregated host cells.

Herring. A similar response was observed and yellow bodies were seen frequently. Aggregations of oocysts were found, with some of the unsporulated forms disintegrating and dispersing their granules (Fig. 2). Staining of yellow bodies again showed the presence of lipofuscin, while the unstained part consisted of amylopectin from the parasite and lipids from host hepatocytes.

Norway pout. Sporulated and unsporulated oocysts were always isolated and no yellow bodies were seen. Leucocytes were occasionally observed attached to sporulated oocysts.

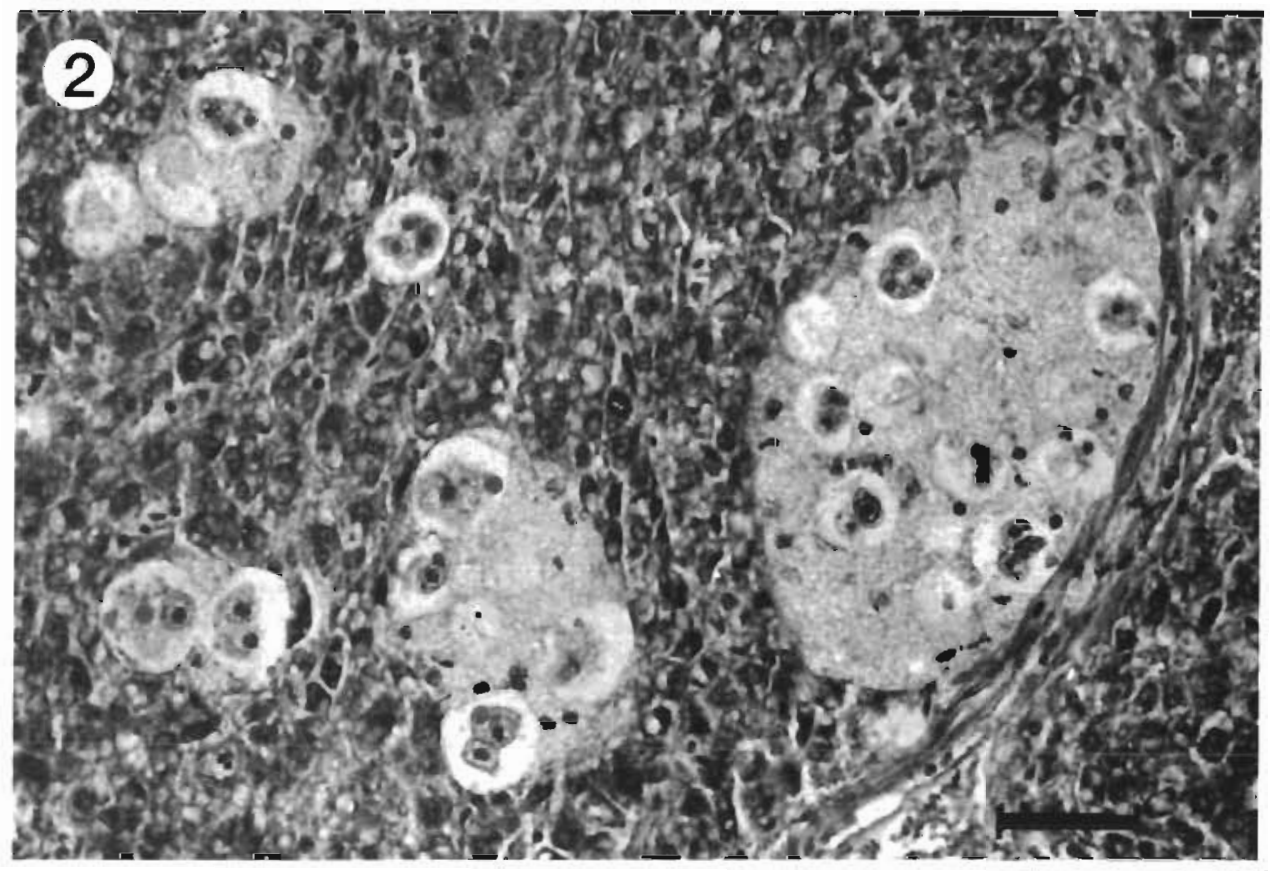

Fig. 2. Goussia clupearum. Aggregations of unsporulated and sporulated oocysts in the liver of a herring. Scale bar $=30 \mu m$. 


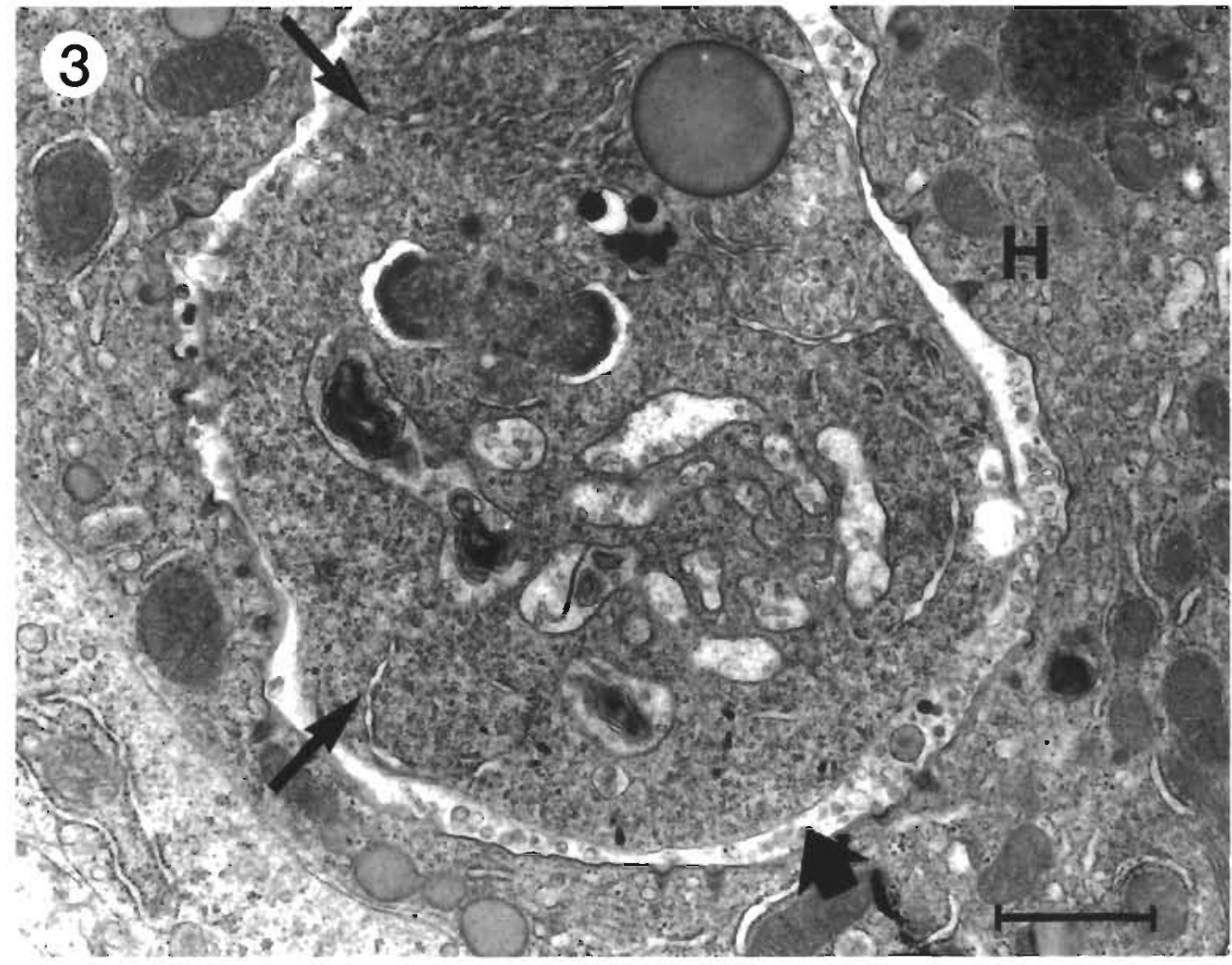

Fig. 3. Goussia clupearum. Macrogamont (thin arrows) inside parasitophorous vacuole (thick arrow) in a hepatocyte (H). Scale bar $=1 \mu \mathrm{m}$

Poorcod. Intensities of infection were much lower than in the other 3 hosts investigated. Only a few sporulated oocysts were found and there was no evidence of host response.

\section{Electron microscopy}

Mackerel and herring. Hepatocytes infected by early stages of Goussia clupearum showed little or no change (Fig. 3), but some hepatocytes containing macrogamonts had hypertrophied mitochondria, hypertrophied rough endoplasmic reticulum (RER) vesicles and dense granules. Hepatocytes containing macrogametes showed further signs of degeneration, with only some lipid droplets, mitochondria and RER remaining identifiable, in sharp contrast to surrounding uninfected hepatocytes. Inside these infected hepatocytes the macrogametes were also degenerating (Fig. 4). Lymphocytes were the most common inflammatory cells present and were sometimes observed adjacent to degenerate macrogametes (Fig. 5). Aggregations of amylopectin granules phagocytised by leucocytes were frequently found (Fig. 6). Degenerate macrogametes were seen within phagacytic cells containing dense inclusions (Figs $7 \& 8$ ), and eosinophils were seen near to some parasites (Fig. 9). Type III granulocytes of about $6.7 \mu \mathrm{m}$ with large eccentric nuclei, patchy chromatin, RER and dense granules were present in the livers of infected herring. The host response did not appear to vary with the age of the fish.

Norway pout. Degenerate infected hepatocytes were seen with fewer ribosomes than uninfected cells and with irregularly shaped mitochondria. Host cells about $12 \mu \mathrm{m}$ long with a single nucleus and many dense inclusions were seen close to oocysts. One very degenerate oocyst inside a degenerate hepatocyte was surrounded by electron-dense structures that may have been lipofuscin. All that remained of the oocyst was the wall and some electron-dense material remnants of the cytoplasm. A layer of electron-dense material was attached to part of the oocyst wall (Fig. 10).

Poorcod. Some macrogamonts, macrogametes and sporulated oocysts were seen inside intact hepatocytes and there was no evidence of host response. Some hepatocytes infected by macrogamonts had glycogen granules inside the parasitophorous vacuole and in the cytoplasm (Fig. 11). 


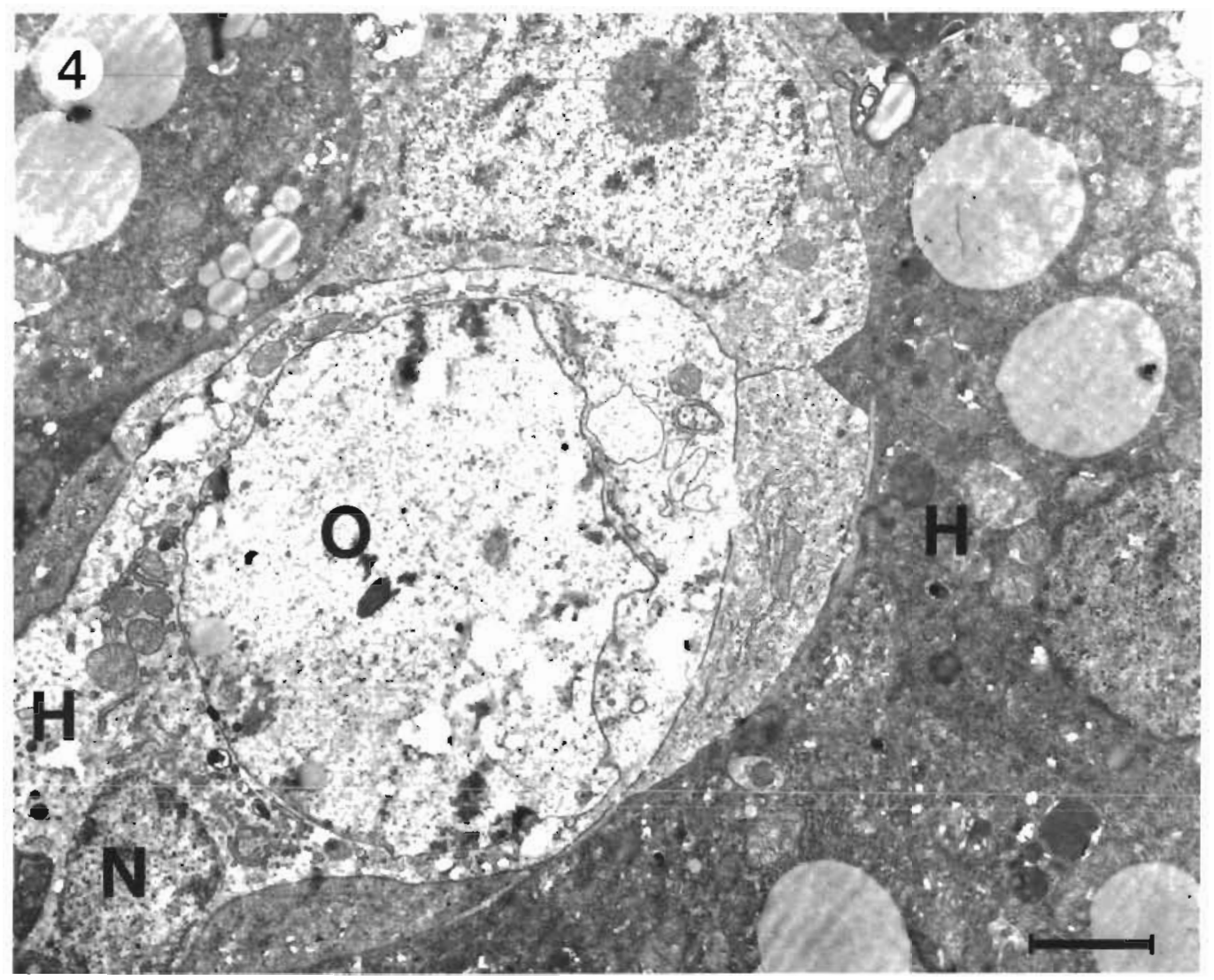

Fig 4. Goussia clupearum. Degenerate oocyst (O) inside degenerate hepatocyte $(\mathrm{H})$ The hepatocyte contains only a few deformed mitochondna, degenerate nucleus (N). some endoplasmic retıculum and Golgi cisternae. Scale bar $=2 \mu \mathrm{m}$

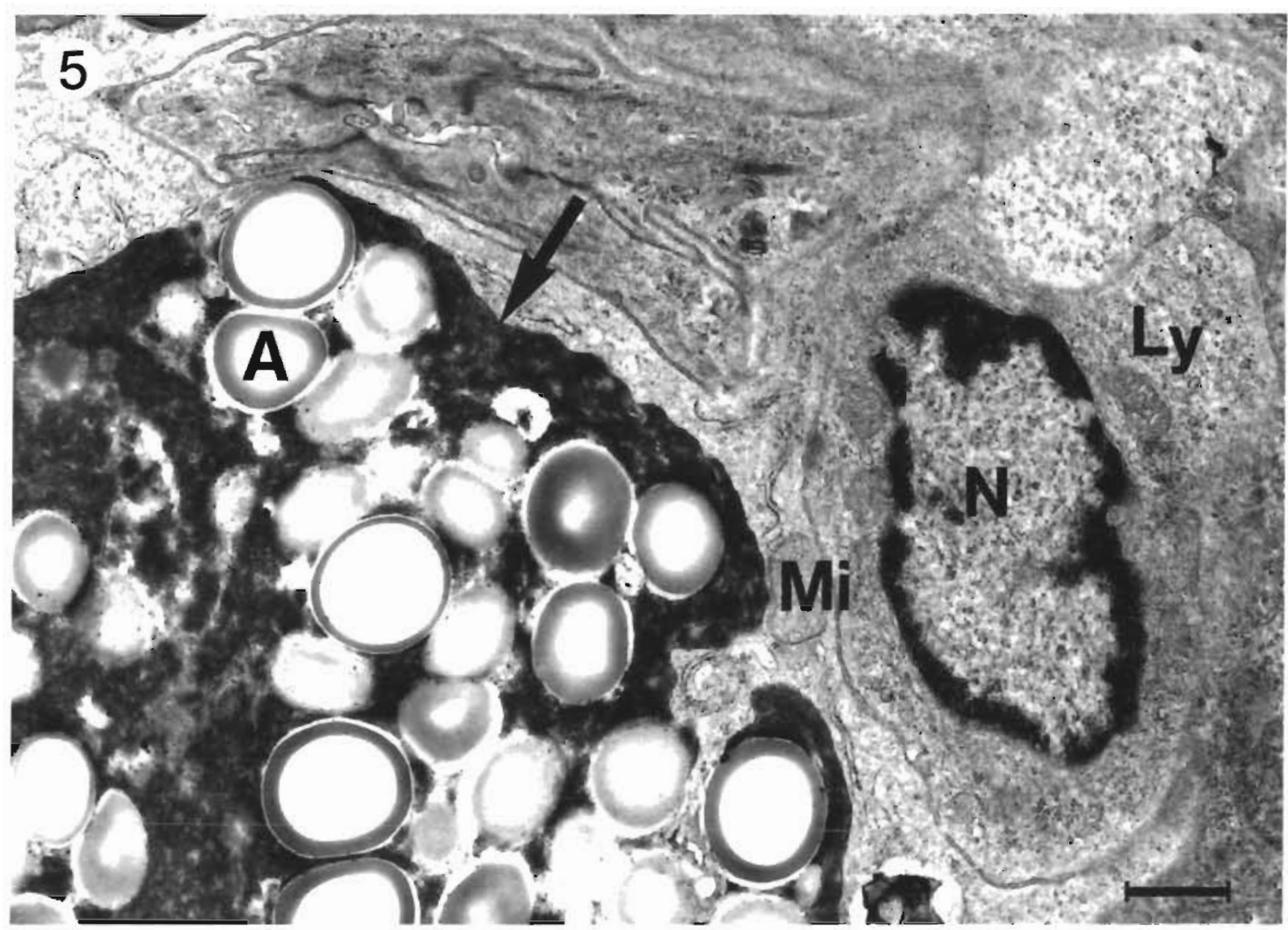

Flg 5 Goussia clupearum Degenerate macrogamete (arrowed) with adjacent Iymphocyte (Ly). A: amylopectin; Mi: mitochondria; $N$ nucleus Scale bar $=1 \mu \mathrm{m}$ 


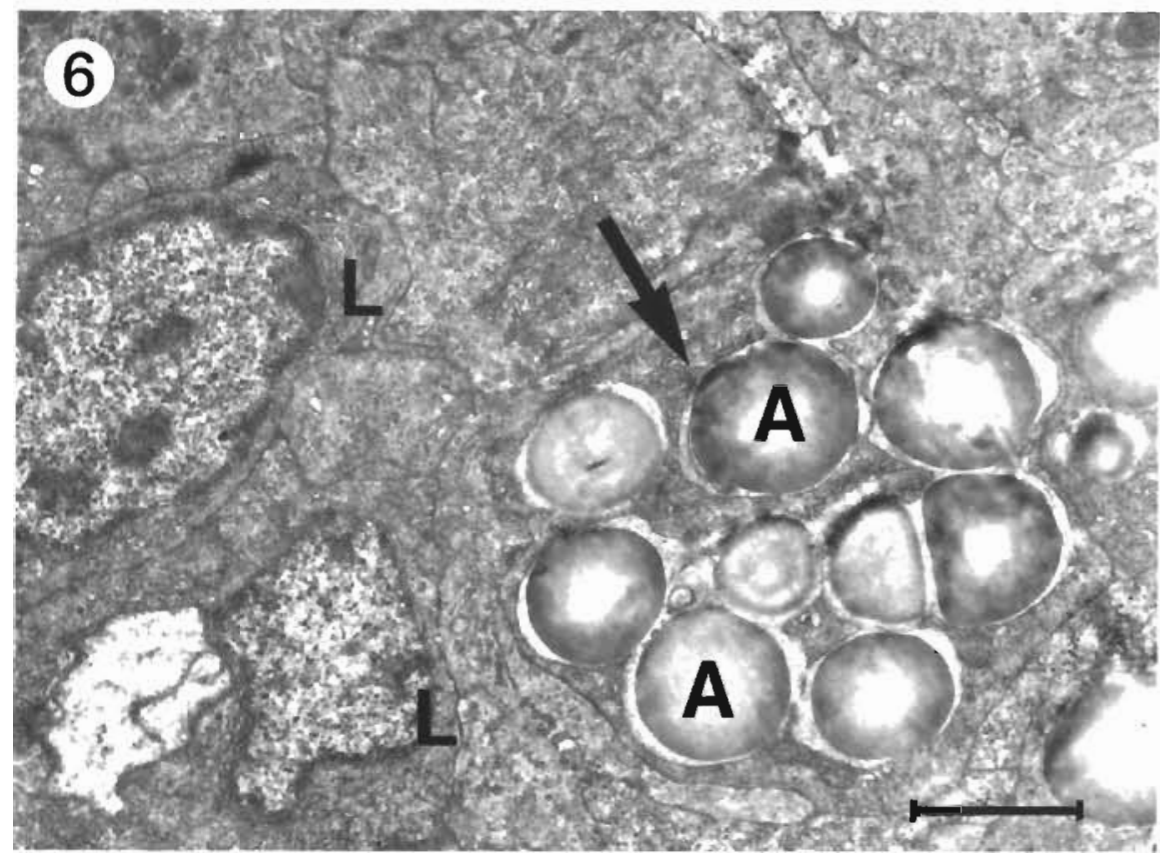

Fig. 6. Goussia clupearum. Degenerate macrogamete (arrowed) A. amylopectun, L leucocytes Scale bar $=2 \mu \mathrm{m}$

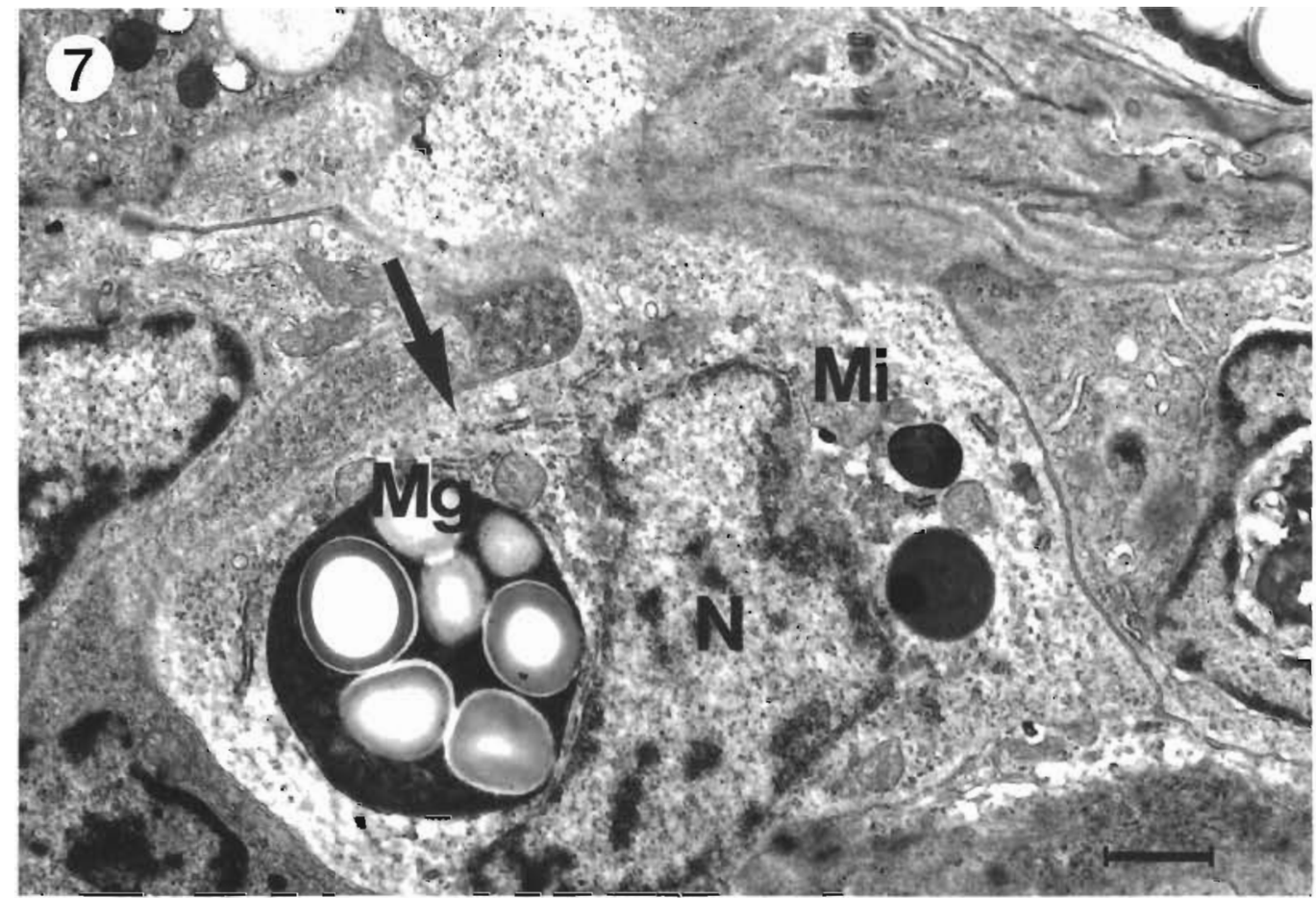

Fig. 7. Goussia clupearum. Degenerate macrogamete (Mg) inside a macrophage (arrowed) with irregular nucleus (N). mitochondria (Mi), some electron-dense inclusions and endoplasmic retıculum Scale bar $=1 \mu \mathrm{m}$ 


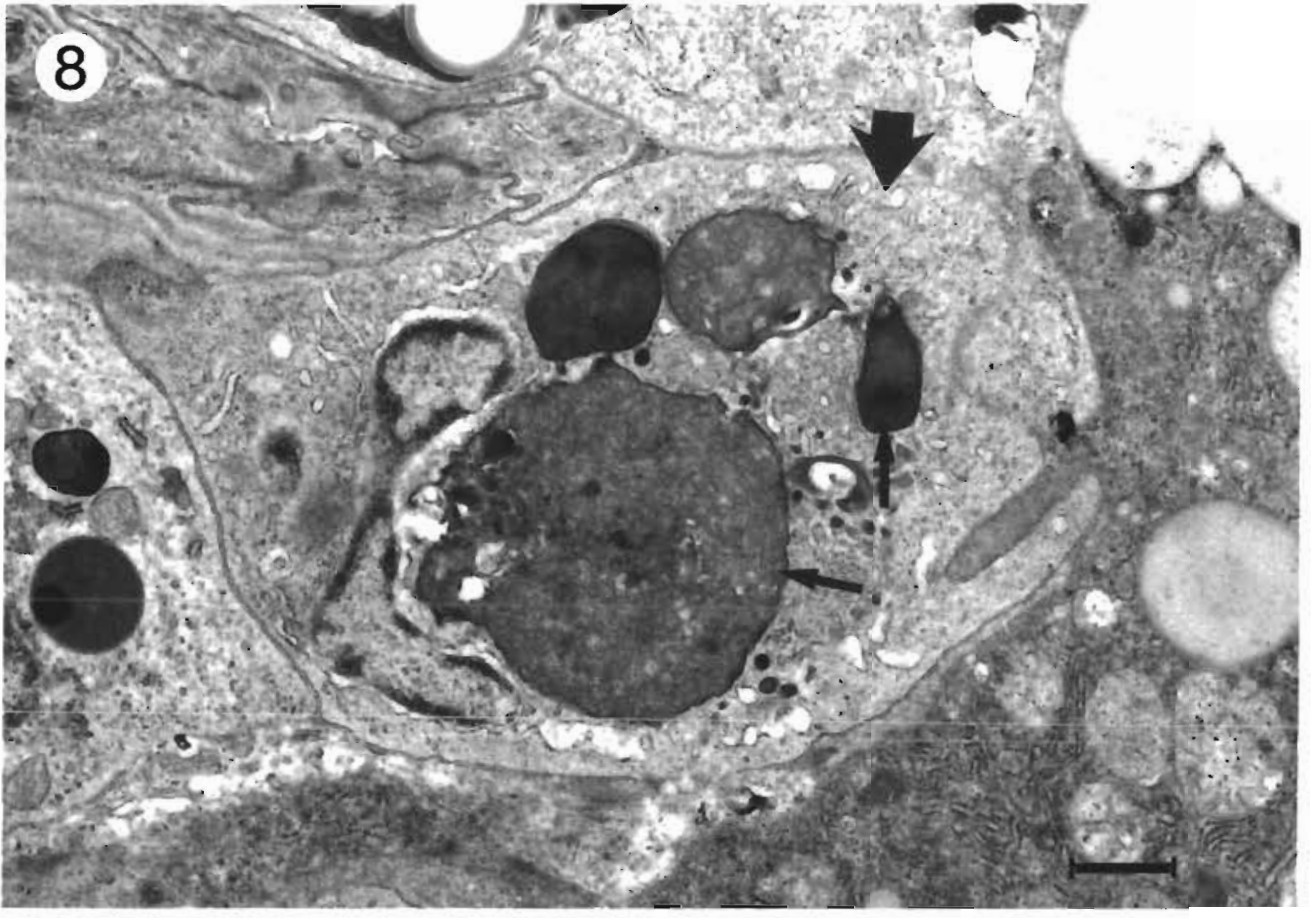

Fig. 8. Goussia clu pearum. Macrophage (thick arrow) containing debris of degenerate macrogamete and electron-dense inclusions (thin arrows). N: nucleus. Scale bar $=1 \mu \mathrm{m}$.

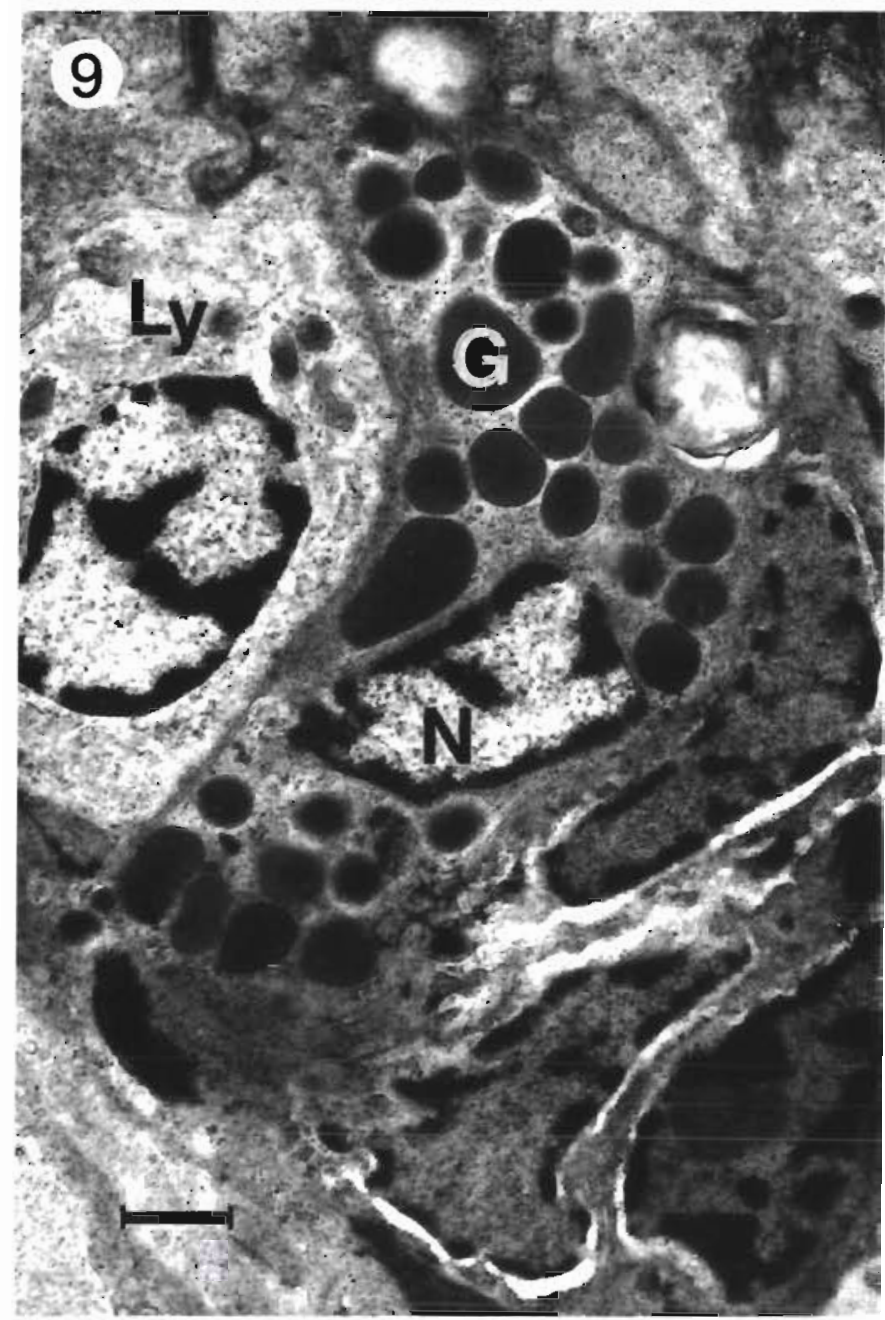

\section{DISCUSSION}

Some species of Goussia infecting fish are known to be serious pathogens. G. carpelli and $G$. subepithelialis both cause severe intestinal pathology in cyprinid fish (Marincek 1973, Pellérdy 1974, Kent \& Hedrick 1985), while heavy infections of $G$. gadi and $G$. caseosa can lead to destruction of the swimbladder of their fish hosts Melanogrammus aeglefinus and Macrourus berglax respectively (Odense \& Logan 1976, Lom \& Dyková 1982). MacKenzie (1981) found that heavy infections of $G$. clupearum (as Eimeria sp.) caused severe emaciation, macroscopic lesions and reduction of the liver in blue whiting. In the present study macroscopic lesions were not observed in the livers of the 4 host species investigated.

Yellow bodies similar to those found in mackerel and herring in the present study have been reported in association with other coccidians infecting the intestine and liver of fish (Molnár 1981, Kent \& Hedrick 1985, Daoudi et al. 1988). In liver tissue they appear to consist of degenerate hepatocytes, oocysts and macrogametes and contain lipofuscin.

Daoudi et al. (1986) found no evidence of host response in the livers of 2 species of mackerel,

Fig. 9. Goussia clupearum. Eosinophil near infected hepatocytes of a herring. $\mathrm{N}$ : nucleus of eosinophil; $\mathrm{G}$ : dense granules of eosinophil; Ly: lymphocyte. Scale bar $=1 \mathrm{um}$ 
Scomber scombrus and S. japonicus, heavily infected with Goussia clupearum, but Morrison \& Hawkins (1984) described some histopathological effects of $G$. clupearum on the liver of herring They found that host inflammatory cells accumulated near some oocysts, host leucocytes sometimes surrounded degenerating sporonts, and some phagocytic host cells contained amylopectin granules. In the present study, host response by herring and mackerel to G. clupearum involved 2 components: a phagocytic one represented by macrophages and another represented by lymphocytes and granulocytes. Some phagocytic cells contained degenerate macrogametes and amylopectin granules. According to Lom et al (1991) the amylopectin granules are the remains of abortive oocysts. A cell similar to the Type III granulocyte of Hawkins et al. (1981) from killifish infected with Calyptospora funduli was found in the livers of herring infected with $G$. clupearum, but the cells in herring were smaller at $6.7 \mu \mathrm{m}$ diameter than those from killifish at 8.0 to $8.5 \mu \mathrm{m}$.

Fig. 10. Goussia clupearum. Degonerate oocyst (O) inside degenerating hepatocyte $(\mathrm{H})$ of Norway pout, containing electron-dense inclusions. Scale bar $=2 \mu \mathrm{m}$

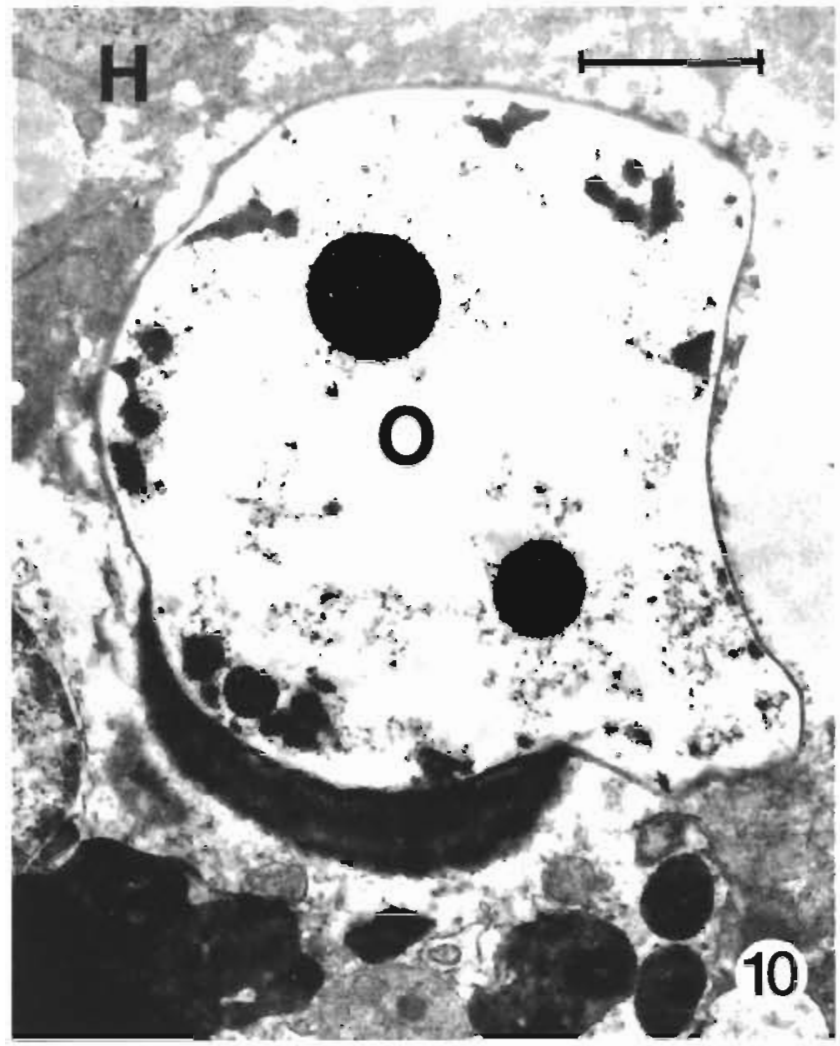

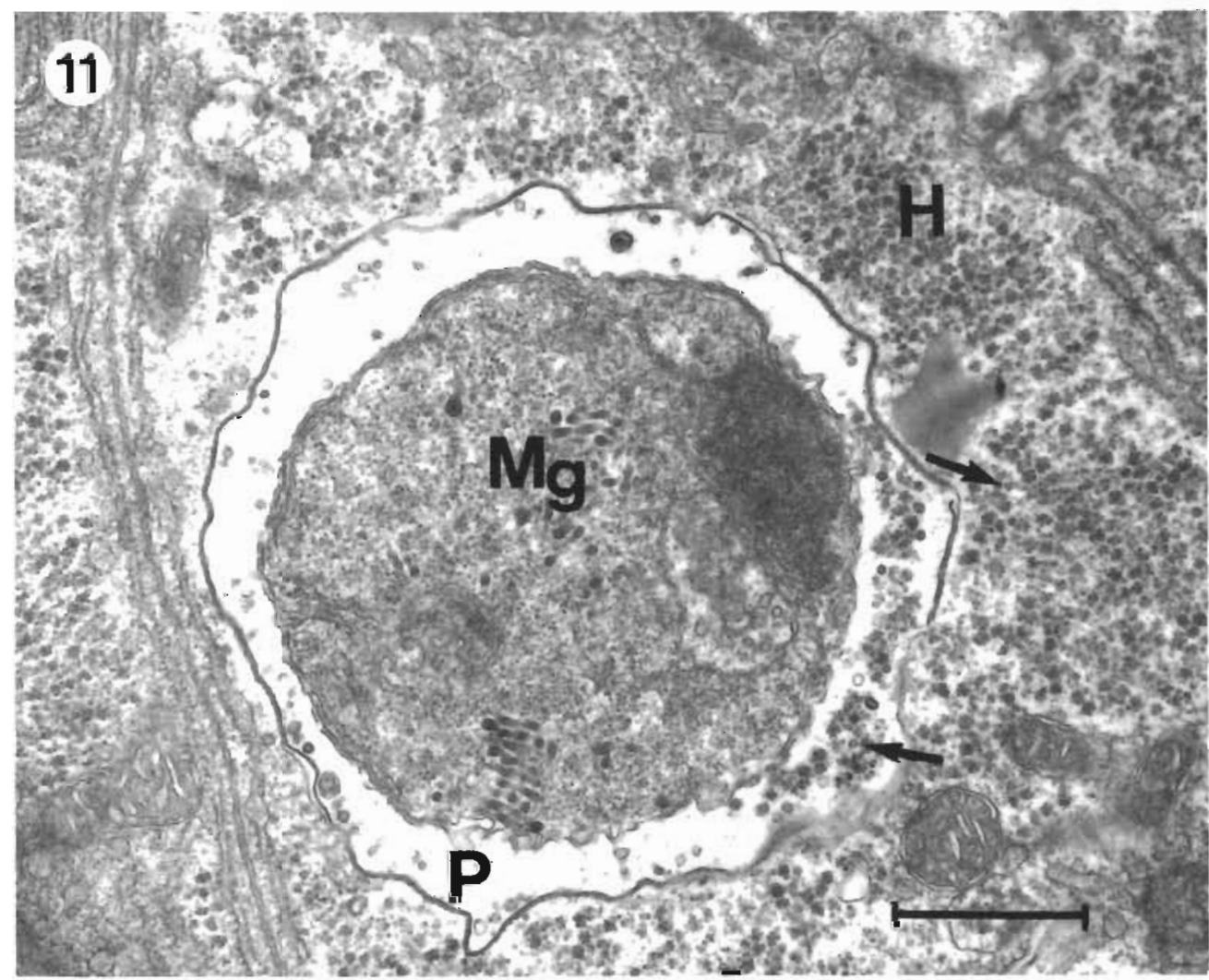

Fig. 11. Goussia clupearum. Macrogamont (Mg) inside parasitophorous vacuole (P) in a hepatocyte (H) of poorcod. Note glycogen granules (arrowed) inside the vacuole and in the hepatocyte. Scale bar $=1 \mu \mathrm{m}$ 
A feature of coccidian infections of fish appears to be that the later developmental stages of the parasites are those that elicit the strongest host response. As in the present study, Hawkins et al. (1981) and Vogelbein et al. (1987) found little response from fish hosts to merogonic stages of the liver coccidian Calyptospora funduli, but a strong response to its macrogametes and oocysts. Meronts and merozoites of Eimeria sinensis caused damage to intestinal epithelial cells of its fish host wihout eliciting inflammation or haemorrhage (Molnár 1976).

This study suggests that in the 4 species of fish investigated, liver coccidiosis is well controlled by the hosts' inflammatory systems and that Goussia clupearum is therefore not a serious pathogen of these fish. This is in contrast to the severe pathology described in blue whiting by Mackenzie (1981), caused by what appears to be the same parasite.

Acknowledgements. This work was supported by a research grant of JNICT-Junta Nacional de Investigaçào Cientifica e Técnologica, Lisbon, to G.C.

\section{LITERATURE CITED}

Culling, F. F. A. (1974). Handbook of histopathological and histochemical techniques. Butterworths \& Co. Publ. Ltd, London

Daoudi, F., Blanc, E., Marqués, A., Bouix, G. (1986). L'action histopathologique de quelques poissons mediterranéens (Golf du Lion). In: Vivares, C. P., Bonami, J. R., Jaspers, E (eds.) Pathology in marine aquaculture. Spec. Publ. Eur. Aquacult. Soc. 9: 111-115

Daoudi, F., Radujkovic, B., Marqués, A., Bouix, G. (1988) Pathogenicity of the coccidian Goussia thelohani in liver and pancreatic tissues of Symphodus tinca. Bull. Eur. Ass. Fish Path. 8: 55-57

Dyková, I., Lom, J. (1981). Fish coccidia: critical notes on life cycles, classification and pathogenicity. J. Fish Dis. 4: 487-505

Dyková, I., Lom, J. (1983). Fish coccidia: an annotated list of described species. Folia Parasitol. (Prague) 30: 193-208

Hawkins, W. E., Solangi, M. A., Overstreet, R. M. (1981). Ultrastructural effects of the coccidium Eimeria funduli

Responsible Subject Editor: W. Körting, Hannover, Germany
Duszynski, Solangi and Overstreet 1979, on the liver of killifishes. J. Fish Dis. 4: 281-295

Jones, J. B. \{1990\}. Goussia auxidis (Dogiel 1948) (Apicomplexa: Calyptosporidae) from tuna (Pisces: Scombridael in the South Pacific. J. Fish Dis. 13: 215-224

Kent, M. L., Hedrick, R. P. (1985). The biology and associated pathology of Goussia carpelli in goldfish Carassius auratus. Fish Pathol. 20: 485-494

Lom, J., Dyková, I. (1982). Some marine fish coccidia of the genera Eimeria Schneider, Epieimeria Dyková \& Lom and Goussia Labbé. J. Fish Dis. 5: 309-321

Lom, J., Steinhagen, D., Körting, W., Dyková, I. (1991). Oocyst formation in the coccidian parasite Goussia carpelli. Dis. aquat. Org. 10: 203-209

Love, M. S., Moser, M. (1983). A checklist of parasites of California, Oregon and Washington marine and estuarine fishes. NOAA Tech. Rep. NMFS SSRF 777

Mackenzie, K. (1981). The effect of Eimera sp. infection on condition of the blue whiting, Micromesistius poutassou. J. Fish Dis. 4: 473-486

Marincek, M. (1973). Les changements dans le tube digestif chez Cyprinus carpio ते la suite de l'infection par Eimeria subeputhellalis. Acta Protozool. 12: 217-224

Molnár, K. (1976). Histological study of coccidiosis in the silver carp and the bighead by Eimeria sinensis Chen, 1956. Acta Vet. Acad. Sci. Hung. 26: 303-312

Molnár, K. (1981). Some peculiarites of oocyst rejection of fish Coccidia. In: Olah, J., Molnár, K., Jeney, Z. (eds.) Fish, pathogens and environment in European polyculture. Fish. Res. Inst., Szarvas, p. 170-183

Morrison, C. M., Hawkins, W. E. (1984). Coccidians in the liver and testis of the herring Clupea harengus L. Can. J. Zool. 62: $480-493$

Odense, P. H., Logan, V. H. (1976). Prevalence and morphology of Eimeria gadi (Fiebiger 1913) in the haddock. J. Protozool. 23: $564-570$

Oliviera, M. F. T., Hawkins, W. E., Overstreet, R. M., Fournie, J. W. (1993). Calyptospora funduli (Apicomplexa, Calyptosporidae) in the liver of the Gulf toadfish, Opsanus beta. J. Helm. Soc. Wash. 60: 273-276

Overstreet, R. M., Hawkins, W. E., Fournie, J. W. (1984). The coccidian genus Calyptospora $\mathrm{n} . \mathrm{g}$. and family Calyptosporidae n. fam. (Apicomplexa), with members infecting primarily fishes. J. Protozool. 31, 332-339

Pellérdy, L. (1974). Coccidia and coccidiosis, 2nd edn. Akadeniai Kiado, Budapest

Vogelbein, W. K., Fournie, J. W., Overstreet, R. M. (1987). Sequential development and morphology of experimentally induced hepatic melano-macrophage centres in Rivulus marmoratus. J Fish Biol. 31 (Suppl. A): $145-153$

Manuscript first received: June 9,1993

Revised version accepted: November 30, 1993 